\title{
ACCURACY OF GEODETIC SURVEYS IN CADASTRAL REGISTRATION OF REAL ESTATE: VALUE OF LAND AS DETERMINING FACTOR
}

\author{
Andrii Martyn $^{1}$, Ivan Openko ${ }^{1}$, Taras Ievsiukov ${ }^{1}$, Oleksandr Shevchenko ${ }^{1}$, Artem Ripenko ${ }^{2}$ \\ ${ }^{1}$ National University of Life and Environmental Sciences of Ukraine, Ukraine; ${ }^{2}$ Odessa Research \\ Institute for Forensic Examination of the Ministry of Justice of Ukraine, Ukraine \\ martyn@nubip.edu.ua,ivan_openko@ukr.net, taras.yevsyukov@gmail.com, \\ shevchenko_ov90@ukr.net, ripenko@ukr.net
}

\begin{abstract}
For millennia, the geodesic industry has improved methods and technologies for obtaining information on location of objects on the Earth's surface, the key task being to improve the accuracy and reliability of measurements. At the same time, in recent decades, the rapid development of positioning technologies based on satellite radio navigation systems has created prerequisites for a situation, where the acceptable accuracy of determining the geodetic characteristics of real estate becomes quite affordable even using non-specialized geodetic equipment, including personal mobile devices. The article shows that the error in determining the area of land for registration of rights to real estate has its own "cost", which depends on the value of real estate in the area of survey. By the example of model sites, it is shown that further improvement of the accuracy of engineering surveying to determine the spatial characteristics of real estate objects would be economically feasible only if the cost of geodetic surveys (including the cost of purchasing new geodetic equipment, payment for labor of specially trained engineers, additional technical services and etc.) will not exceed the "cost of error" to determine the area of the site. Using the example of Ukraine, it is shown that the most accurate geodetic surveys (determining turning points of land borders with an accuracy of more than $0.02 \mathrm{~m}$ ) are economically feasible only when the market value of a land plot exceeds USD 208 per square meter.
\end{abstract}

Keywords: accuracy, surveys, geodesy, value, land, cadastre.

\section{Introduction}

At the current pace of development of satellite and network technologies, the role of man in performing topographic and geodetic surveys in the field of land management is decreasing. In particular, today the use of GNSS-technologies has practically replaced the basic methods of creating geodetic networks for various geodetic works (triangulation, trilateration, polygonometry), including determination of the coordinates of the turning points of the land plot during cadastral surveys and land inventories, establishment of boundaries of the land plot on the ground.

Existing differentiation of accuracy and cost of topographic and geodetic surveys, in particular, for the purpose of inventory of land [1], creates preconditions for further research in the field of engineering economics, namely:

- definition of the dependence of the cost of topographic and geodetic works in the field of land management on the accuracy of these works;

- estimation of the efficiency of using modern satellite technologies for the purpose of the real estate cadastre (especially, when installing (fixing) the turning points of the land plot within the permissible error of 0.5 meters), and determining the prospects for using the mobile gadgets (smartphones, tablets, etc.) for these purposes;

- establishment of acceptable accuracy of topographic and geodetic surveys in the real estate cadastre depending on the market value of the land plot.

Problems of establishing the requirements for the accuracy of land cadastral papers were undertaken by various scientists, in particular, Zhilinsky (2013) tried to investigate the influence of economic factors on the accuracy of geodetic measurements during cadastral works, and established, in the conditions of the city of Lviv, the size of the error of determining the area of land in cash equivalent [2].

Petrov and Tserklevich (2011) [3] found that the change in the mean square error (MSE) of determining the coordinates of the points of land plot boundary proportionally affects the change in the MSE of their area. Kristin M. Stock (1998) [4] carried out a sociological study, in which she insisted on the accuracy of establishing the boundaries of the land in the countryside. It is determined that the overwhelming majority of the surveyed landowners, including the local authorities and relevant municipal organizations in the study area, require the maximum accuracy of establishing the boundaries of the land plot in the range of \pm 0.2 and $\pm 0.5 \mathrm{~m}$. 
An analysis of the historical stages of development of technologies in geodesy and their impact on the accuracy of land cadastral surveys is presented in the scientific publication Belle A. Craig and Jerry L. Wahl (2003) [5].

At the same time, Tim Burch (2017) in his article draws attention to the fact that the development of modern GNSS technologies reduces the relevance of the classical study of geodetic surveying methods and minimizes the role of a certified geodesist specialist in the implementation of various types of land cadastral work [6].

\section{Materials and methods}

The current state of the development of GNSS technologies allows to get the coordinates of the points with the maximum possible accuracy of 1 meter (raw data by satellite observations) even under favorable observation conditions (PDOP, GDOP, etc.).

It is clear that for the purpose of land management, the accuracy of positioning in $1 \mathrm{~m}$ is not permissible, such circumstances directly influenced the development of appropriate positioning methods for achieving higher accuracy in determining the planned height position of the reference points: the static method; fast static; RTK - Real Time Kinematics.

However, the use of RTK mode involves receiving amendments from the base station, that is, from the receiver, which is set at a point with a known (true) coordinate, points of the state geodetic network. To date, such base stations have permanent stations.

In Ukraine, the main organizations that hold national networks of GNSS permanent stations are private companies, as described in Table 1.

Table 1

Analysis of private permanent networks to provide
GNSS surveillance data adjustment in Ukraine

\begin{tabular}{|c|c|c|c|}
\hline Name & System Solutions & $\begin{array}{c}\text { TNT TPI GNSS } \\
\text { Network }\end{array}$ & Zak Pos \\
\hline 1 & 2 & 3 & 4 \\
\hline $\begin{array}{l}\text { GNSS brand } \\
\text { equipment offered } \\
\text { by the company }\end{array}$ & Leica Geosystems & TOPCON & Trimble \\
\hline \multicolumn{4}{|c|}{ Cost of services: } \\
\hline \multicolumn{4}{|c|}{ Real-time positioning (RTK) } \\
\hline 1 hour & - & 0.4 USD & - \\
\hline 1 minute & $\begin{array}{c}0.1 \text { USD } \\
\text { RINEX \& Virtual } \\
\text { RINEX - } 0.04 \text { USD } \\
\end{array}$ & 0.02 USD & 0.06 USD \\
\hline $\begin{array}{c}1 \text { month } \\
\text { subscription }\end{array}$ & 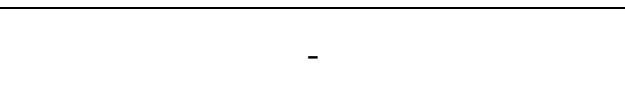 & 21.3 USD & 41.3 USD \\
\hline $\begin{array}{c}\text { Subscription } 3 \\
\text { months }\end{array}$ & 207 USD & 57 USD & - \\
\hline $\begin{array}{c}\text { Annual } \\
\text { subscription }\end{array}$ & 571.8 USD & 202.7 USD & 412.5 USD \\
\hline $\begin{array}{l}\text { Post processing } \\
\text { raw file in RINEX } \\
\text { format }\end{array}$ & 1.78 USD & - & - \\
\hline Equipment rental & $\begin{array}{c}1 \text { day }-35.6 \text { USD } \cdot \text { day }^{-1} \\
\text { 2-6 days }-28.4 \text { USD } \text { day }^{-1} ; \\
\text { 7-13 - days } 27.0 \text { USD } \cdot \text { day }^{-1} ; 2 \text { weeks - } \\
\text { 311.0 USD; month }-604.6 \text { USD }\end{array}$ & $\begin{array}{l}\text { Do not provide such } \\
\text { services (only } \\
\text { the sale of } \\
\text { equipment) }\end{array}$ & $\begin{array}{l}\text { Do not } \\
\text { provide } \\
\text { such } \\
\text { services }\end{array}$ \\
\hline Precision farming & from 248.9 USD & from 32.0 USD & - \\
\hline
\end{tabular}

The above information was taken into account in further development of the estimate of the cost of geodetic works in establishing the boundaries of the land plot (Table 2). 
Calculation of the cost of geodetic works in relation to fixing the boundaries of the land plot

\begin{tabular}{|c|c|c|c|c|c|}
\hline \multirow{3}{*}{\multicolumn{2}{|c|}{$\begin{array}{l}\text { Level of acceptable accuracy for } \\
\text { the purpose of inventory of land }\end{array}$}} & \multicolumn{2}{|c|}{$\mathrm{I}$} & \multirow{2}{*}{ II } & \multirow{2}{*}{ III } \\
\hline & & $\mathrm{a}$ & $\mathrm{b}$ & & \\
\hline & & up to $2 \mathrm{~cm}$ & $2-10 \mathrm{~cm}$ & $10-20 \mathrm{~cm}$ & $20-50 \mathrm{~cm}$ \\
\hline \multirow{2}{*}{$\begin{array}{c}\text { GNSS } \\
\text { technology }\end{array}$} & $\begin{array}{l}\text { Type of the most } \\
\text { effective method } \\
\text { for achieving the } \\
\text { correct accuracy }\end{array}$ & Static & $\begin{array}{c}\text { Real Time } \\
\text { Kinematic (RTK) }\end{array}$ & RTK & RTK \\
\hline & Geodetic binding & $\begin{array}{l}\text { State geodetic } \\
\text { network (reference } \\
\text { points) }\end{array}$ & $\begin{array}{c}\text { Reference } \\
\text { points + state } \\
\text { geodetic network } \\
\text { for calibration }\end{array}$ & $\begin{array}{c}\text { Reference } \\
\text { points }+ \text { state } \\
\text { geodetic network } \\
\text { for calibration }\end{array}$ & Reference points \\
\hline \multirow{4}{*}{$\begin{array}{l}\text { Estimate of } \\
\text { the cost of } \\
\text { geodetic } \\
\text { works in } \\
\text { relation to the } \\
\text { establishment } \\
\text { of the } \\
\text { boundaries of } \\
\text { the land plot } \\
* * *\end{array}$} & $\begin{array}{l}\text { Cost of data on } \\
\text { the coordinates of } \\
\text { the item of the } \\
\text { state geodetic } \\
\text { network } \\
\text { (reference } \\
\text { points) } *\end{array}$ & $\begin{array}{c}3 \times 5.3 \text { USD }= \\
16 \text { USD }\end{array}$ & 5.3 USD & 5.3 USD & - \\
\hline & $\begin{array}{l}\text { Rent for the } \\
\text { required geodetic } \\
\text { equipment } * *\end{array}$ & $\begin{array}{c}\text { Base + Rover } \\
\text { (GNSS Leica } \\
\text { GS08Plus } \\
\text { (GS12) + CS10) - } \\
\text { 71.1 USD. day }{ }^{-1} \text {; } \\
\text { Tacheometer } \\
\text { (Leica TS09plus } \\
\text { R500 (5"))- } \\
\text { 35.6 USD } \cdot \text { day }^{-1} \text {; }\end{array}$ & $\begin{array}{c}\text { Rover (GNSS } \\
\text { Leica GS08Plus } \\
(\text { GS12) + CS10) } \\
- \\
35.6 \text { USD. day }{ }^{-1} ;\end{array}$ & $\begin{array}{c}\text { Rover (GNSS } \\
\text { Leica GS08Plus } \\
\text { (GS12) + CS10) } \\
- \\
\text { 35.6 USD. day }{ }^{-1}\end{array}$ & $\begin{array}{c}\text { Rover (GNSS } \\
\text { Leica GS08Plus } \\
(\text { GS12) + CS10) } \\
- \\
\text { 35.6 USD. day }{ }^{-1} \text {; }\end{array}$ \\
\hline & $\begin{array}{l}\text { Cost of receiving } \\
\text { RTK corrections } \\
* *\end{array}$ & - & $\begin{array}{l}207.0 \text { USD per } 3 \\
\text { months } \rightarrow \\
1 \text { day }=2.3 \text { USD }\end{array}$ & $2.3 \mathrm{USD} \cdot \mathrm{day}^{-1}$ & 2.3 USD day $^{-1}$ \\
\hline & $\begin{array}{l}\text { Total } \\
\end{array}$ & 122.7 USD & 43.2 USD & 43.2 USD & 37.9 USD \\
\hline \multicolumn{2}{|c|}{ Number of employees } & 2 & 1 & 1 & 1 \\
\hline \multicolumn{2}{|c|}{$\begin{array}{l}\text { Cost of determining the } \\
\text { boundaries of the land plot }\end{array}$} & $\begin{array}{l}32.0 \text { USD per } \\
\text { point (at the same } \\
\text { time the minimum } \\
\text { cost of departure } \\
\text { of a surveyor is } \\
71.2 \text { USD) }\end{array}$ & $\begin{array}{l}\text { 10.1 USD per } \\
\text { point (at the same } \\
\text { time the } \\
\text { minimum cost of } \\
\text { departure of a } \\
\text { surveyor is } \\
53.3 \text { USD) }\end{array}$ & $\begin{array}{l}\text { 10.1 USD per } \\
\text { point (at the same } \\
\text { time the } \\
\text { minimum cost of } \\
\text { departure of a } \\
\text { surveyor is } \\
53.3 \text { USD) }\end{array}$ & $\begin{array}{l}\text { 7.1 USD per } \\
\text { point }\end{array}$ \\
\hline
\end{tabular}

* - according to the Research Institute of Geodesy and Cartography [7];

** - according to System Solutions (Table 1);

$* * *$ - in the indicated estimate there are no calculations for logistics costs, since these data are individual for each object

In Ukraine, in accordance with the Resolution of the Cabinet of Ministers of Ukraine dated May 23, 2012, No. 513 "On Approval of the Procedure for Land Inventory Management", the error of determining the turning points of land plots relative to the nearest points of the state geodetic network should not exceed [8]:

- in Kyiv, Sevastopol and cities of regional subordination - 0.1 meters;

- in other cities and towns - 0.2 meters;

- in villages - 0.3 meters;

- outside of settlements -0.5 meters.

The stated allowable accuracy of determining the position of the turning points of the land plot on the ground has been based on the analysis of the cost of topographic and geodetic works, namely: 
- when choosing effective methods of creating a reference geodetic network - the most accurate differential method in the application of GNSS technologies is the "Static" method, which allows to determine the position of points (sampling ground) to $1 \mathrm{~mm}$, and then, with the help of geometry, fix the boundaries of the land plot to within 10-20 mm; At the same time, the application of the polygonometric method, in modern technologies, is inappropriate, except for the presence of dense building, densely planted areas - forest arrays, etc.

- in determining the required geodetic equipment and the number of performers. According to the above methods, for the purpose of achieving the appropriate precision, we have identified the kits of the required equipment and presented their market lease payment [9], determined on the basis of (Table 2) the amount of payment for receiving RTK corrections and the cost of coordinates of the outgoing points of the State Geodetic Network [7].

It is important to note that at the time of drafting the estimate of the cost of land cadastral works for fixing the boundaries of the land, the rate of USD - 28.12 UAH to USD (official data of the National Bank of Ukraine as of 18.09.2018), and the average wage in Ukraine - 7621 UAH per month (271 USD) [10].

Thus, from the above calculations in Table 3, we have the cost of geodetic works for fixing the boundaries of the land plot with an accuracy of I-45.27 \% of the average monthly salary in Ukraine and requires two executors, and II - $15.94 \%$ (one performer ), III - $13.97 \%$ (one performer).

In fact, we have established a direct correlation between the accuracy and cost of topographic and geodetic works in relation to fixing the boundaries of the land plot on the ground, that is, with "higher precision" "higher price".

\section{Results and discussion}

According to the results of our analysis, we can further speak about the dubious necessity of conducting high-precision geodetic surveys (in view of their high cost) for the purpose of land cadastre, in particular, inventory of land and the establishment of boundaries of land in the area. We believe that achieving high accuracy in conducting geodetic works in the field of land cadastre is an indirect necessity, which should be determined based on the market value of the surveyed land plot.

Subsequently, our studies concerned the definition of acceptable accuracy of land cadastral work, which in our opinion, should be determined on the basis of economic factors. That is, in order to find out the expediency of implementing high-precision topographic and geodetic works in the field of land cadastre, it is necessary to compare the error of the definition of the area and market value of the corresponding land with the cost of geodetic works.

Conditionally, if a plot of land has the shape of a rectangle, which sides $a$ and $b$ are defined with average square errors $m_{a}$ and $m_{b}$ accordingly, then the error of determining the area of the land $S$, according to the theory of errors, will be determined by the formula

$$
m_{s}^{2}=\left(\frac{\partial S}{\partial a}\right)^{2} \times m_{a}^{2}+\left(\frac{\partial S}{\partial b}\right)^{2} \times m_{b}^{2}
$$

We find partial derivatives:

$$
\frac{\partial S}{\partial a}=b ; \frac{\partial S}{\partial b}=a
$$

Having defined partial derivatives we have the general formula for determining the error of the area of the land plot of a rectangular shape with certain errors in measuring the length $\left(m_{a}\right)$ and width $\left(m_{b}\right)$ :

$$
m_{s}^{2}=b^{2} \times m_{a}^{2}+a^{2} \times m_{b}^{2}
$$

Thus, mathematically proved and quite understandable is the fact that the error in the area of the land will be directly affected by the error of determining the linear elements (boundaries) of the land.

Consequently, in general, if the value of $f$ is expressed in terms of independently measured values $x_{i}(i=1, n)$ - the coefficients, then the mean square error $m_{f}$ of the value of $f$ will be 


$$
m_{f}= \pm \sqrt{\sum_{i=1}^{n} a_{i}^{2} \times m_{i}^{2}}= \pm \sqrt{\left[a^{2} \times m^{2}\right]}
$$

If the measurements $x_{i}(i=1, \bar{n})$ are equivalent and $m_{1}=m_{2}=\ldots=m_{n}=m$, then:

$$
m_{f}= \pm m \sqrt{\left[a^{2}\right]}
$$

The resulting formula for the mean square error is obtained from the relation:

$$
m_{F}^{2}=\left(F_{x}^{\prime}\right)_{0}^{2} \times m_{x}^{2}+\left(F_{y}^{\prime}\right)_{0}^{2} \times m_{y}^{2}+\ldots+\left(F_{u}^{\prime}\right)_{0}^{2} \times m_{u}^{2}
$$

and expressions for partial derivatives of $f$ for arguments $X_{i}$ :

$$
\frac{\partial f}{\partial x_{i}}=a_{i},(i=\overline{1, n}) \text {. }
$$

At the same time, the function to determine the area of the land plot with known coordinates of the turning points will have the following form:

$$
S=\frac{1}{2} \sum_{i}^{n} X_{i}\left(Y_{i+1}-Y_{i-1}\right)
$$

In this case, the margin of error in determining the area of the land will be determined by the following formula:

$$
m_{s}=\sqrt{1 / 4 \sum_{i=1}^{n}\left\{\left(X_{i+1}-X_{i-1}\right)^{2} \times m_{y}^{2}+\left(Y_{i+1}-Y_{i-1}\right)^{2} \times\right\} m_{x}^{2}}
$$

where $m_{x}, m_{y}$ - mean square error of the coordinates of the turning points of the land plot.

In the course of our study, we determined the margin of permissible error in determining the area of land. To do this, simulation was done of the size of the land plot, which in shape corresponded to the figure of a rectangle, with different perimeters (lengths) of the parties in the range from 0.01 ha to

\begin{tabular}{|c|c|c|c|c|c|c|c|c|}
\hline \multirow{5}{*}{ № } & \multirow{5}{*}{$\begin{array}{l}\text { Placement of land } \\
\qquad[8]\end{array}$} & \multirow{5}{*}{$\begin{array}{c}\text { Average } \\
\text { square error of } \\
\text { determining } \\
\text { the position of } \\
\text { the turning } \\
\text { points of the } \\
\text { land (m) [8] }\end{array}$} & \multirow{2}{*}{\multicolumn{6}{|c|}{$\begin{array}{c}\text { Calculation of the error of the area of land, } \mathbf{m}^{\mathbf{2}} \\
\text { Land area, ha }\end{array}$}} \\
\hline & & & & & & & & \\
\hline & & & 5 & 1 & 0.5 & 0.25 & 0.10 & 0.01 \\
\hline & & & \multicolumn{6}{|c|}{ Perimeter, m } \\
\hline & & & 895 & 400 & 283 & 200 & 128 & 40 \\
\hline 1 & 2 & 3 & 4 & 5 & 6 & 7 & 8 & 9 \\
\hline \multirow[t]{2}{*}{1} & \multirow{2}{*}{$\begin{array}{c}\text { Kiev, Sevastopol city } \\
\text { and cities of regional } \\
\text { subordination }\end{array}$} & $\begin{array}{l}\text { to } 0.02 \text { (high } \\
\text { precision) }\end{array}$ & 17.9 & 8 & 5.66 & 4 & 2.56 & 0.8 \\
\hline & & 0.1 & 89.5 & 40 & 28.3 & 20 & 12.8 & 4 \\
\hline 2 & $\begin{array}{l}\text { In other cities and } \\
\text { towns }\end{array}$ & 0.2 & 179 & 80 & 56.6 & 40 & 25.6 & 8 \\
\hline 3 & in villages & 0.3 & 268.5 & 120 & 84.9 & 60 & 38.4 & 12 \\
\hline 4 & $\begin{array}{l}\text { Outside of the } \\
\text { settlement }\end{array}$ & 0.5 & 447.5 & 200 & 141.5 & 100 & 64 & 20 \\
\hline
\end{tabular}
5 hectares. The average quadratic error in determining the position of turning points was determined in accordance with the Resolution of the Cabinet of Ministers of Ukraine dated May 23, 2012 No. 513 [8] (Table 3).

Table 3

\section{Calculation of the error of the area of land}


Thus, we have calculated the errors in determining the area of land $\left(S_{1}=0.01\right.$ ha; $S_{2}=0.10$ ha; $S_{3}=0.25 \mathrm{ha} ; S_{4}=0.50 \mathrm{ha} ; S_{5}=1.00 \mathrm{ha} ; S_{6}=5.00 \mathrm{ha}$ ), taking into account the errors of the position of the turning points $\left(m_{1}=0.02 \mathrm{~m} ; m_{2}=0.1 \mathrm{~m} ; m_{3}=0.2 \mathrm{~m} ; m_{4}=0.3 \mathrm{~m} ; m_{5}=0.5 \mathrm{~m}\right)$ (Table 3).

The next stage of our study was to determine the acceptable accuracy of establishing the boundaries of the land due to its market value. Taking into account the data of Table 2 (cost of topographic and geodetic works) and Table 3 (size of errors in land parcels) and taking into account the norms of the current legislation [8], we determined the minimum size of the land values to achieve cost-effective implementation of high-precision geodetic measurements in the field of inventory of land ( Table 4).

Table 4

Economic feasibility of implementation of topographic and geodetic works

I - Economic feasibility of carrying out topographic and geodetic works with high accuracy

1-a) Mean square error of determination of the position of the turning points of the land plot to $0.02 \mathrm{~m}$

\begin{tabular}{|c|c|c|c|c|c|c|}
\hline Land area, ha & 5.00 & 1.00 & 0.50 & 0.25 & 0.10 & 0.01 \\
\hline Error in the area of the land, $\mathrm{m}^{2}$ & 17.90 & 8.00 & 5.66 & 4.00 & 2.56 & 0.80 \\
\hline $\begin{array}{l}\text { Market value of land to achieve economic effect, } 1 \\
\qquad \mathrm{~m}^{2} \cdot \mathrm{USD}^{-1}\end{array}$ & 9.28 & 20.76 & 29.34 & 41.52 & 64.87 & $\begin{array}{c}207.5 \\
9\end{array}$ \\
\hline
\end{tabular}

II - Economic feasibility of carrying out topographic and geodetic works with the correct accuracy

1) Mean square error of the definition of the position of the turning points of the land plot of $0.1 \mathrm{~m}$ Land area, ha

Error in the area of the land, $\mathrm{m}^{2}$

Market value of land to achieve economic effect, 1 $\mathrm{m}^{2} \cdot \mathrm{USD}^{-1}$

\begin{tabular}{|c|c|c|c|c|c|}
\hline 5.00 & 1.00 & 0.50 & 0.25 & 0.10 & 0.01 \\
\hline 89.50 & 40.00 & 28.30 & 20.00 & 12.80 & 4.00 \\
\hline 0.96 & 2.16 & 3.05 & 4.31 & 6.74 & 21.56 \\
\hline
\end{tabular}

2) Mean square error of the definition of the position of the turning points of the land plot of $0.2 \mathrm{~m}$

\begin{tabular}{|c|c|c|c|c|c|c|}
\hline Land area, ha & 5.00 & 1.00 & 0.50 & 0.25 & 0.10 & 0.01 \\
\hline Error in the area of the land, $\mathrm{m}^{2}$ & 179.00 & 80.00 & 56.60 & 40.00 & 25.60 & 8.00 \\
\hline $\begin{array}{c}\text { Market value of land to achieve economic effect, 1 } \\
\mathrm{m}^{2} \text {. USD }\end{array}$ & 0.48 & 1.08 & 1.52 & 2.16 & 3.37 & 10.78 \\
\hline \begin{tabular}{c}
-1 \\
\hline
\end{tabular}
\end{tabular}

3) Mean square error of the definition of the position of the turning points of the land plot of $0.3 \mathrm{~m}$

\begin{tabular}{|c|c|c|c|c|c|c|}
\hline Land area, ha & 5.00 & 1.00 & 0.50 & 0.25 & 0.10 & 0.01 \\
\hline Error in the area of the land, $\mathrm{m}^{2}$ & 268.50 & 120.00 & 84.90 & 60.00 & 38.40 & 12.00 \\
\hline $\begin{array}{c}\text { Market value of land to achieve economic effect, 1 } \\
\mathrm{m}^{2} \cdot \mathrm{USD}^{-1}\end{array}$ & 0.32 & 0.72 & 1.02 & 1.44 & 2.25 & 7.19 \\
\hline
\end{tabular}

4) Mean square error of the definition of the position of the turning points of the land plot of $0.5 \mathrm{~m}$

\begin{tabular}{|c|c|c|c|c|c|c|}
\hline Land area, ha & 5.00 & 1.00 & 0.50 & 0.25 & 0.10 & 0.01 \\
\hline Error in the area of the land, $\mathrm{m}^{2}$ & 447.50 & 200.00 & 141.50 & 100.00 & 64.00 & 20.00 \\
\hline $\begin{array}{c}\text { Market value of land to achieve economic effect, 1 } \\
\mathrm{m}^{2} \cdot \mathrm{USD}^{-1}\end{array}$ & 0.19 & 0.43 & 0.61 & 0.86 & 1.35 & 4.31 \\
\hline
\end{tabular}

That is, we justified the marginal market value of the land plot, in which the implementation of topographic and geodetic works of appropriate accuracy will be economically feasible in the field of land cadastre.

From the data obtained (Table 4), it is safe to say that precise geodetic work (determination of the position of the turning points of the land plot to $0,02 \mathrm{~m}$ ), in view of their high cost, in comparison with others, is expedient to carry out in cases, where the market value of $1 \mathrm{~m}^{2}$ the land plot reaches $207.59 \mathrm{~m}^{2} \cdot \mathrm{USD}^{-1}$ when establishing boundaries of a land plot with a total area of 0,01 hectares; $64.87 \mathrm{~m}^{2} \cdot \mathrm{USD}^{-1}$ - land area of 0.10 hectares; $41.52 \mathrm{~m}^{2} \cdot \mathrm{USD}^{-1}$ - land area of 0.25 hectares; $29.34 \mathrm{~m}^{2} \cdot \mathrm{USD}^{-1}$ - land area of 0,50 hectares; $20.76 \mathrm{~m}^{2} \cdot \mathrm{USD}^{-1}$ - land area of 1.00 hectares; $9.28 \mathrm{~m}^{2} \cdot \mathrm{USD}^{-1}$ - land area of 5.00 hectares.

At the same time, given the high cost of high-precision geodetic equipment and the rapid development of modern telecommunication technologies (smartphones, tablets) with the support of positioning technologies (GNSS-technology), it is extremely important to provide a scientific and practical evaluation of the use of these electronic gadgets in the implementation of land -capital works (surveying, inventory of land, establishing boundaries of the land plot on the ground), especially when the marginal error of the performance of these works must be achieved in the range $20-50 \mathrm{~cm}$, 
depending on the location of the land (in other cities and towns -0.2 meters, in villages -0.3 meters, outside the settlements -0.5 meters [8]).

For example, to date, Xiaomi has been developed and offered to users, the new flagship Xiaomi Mi 8, equipped with a dual-frequency GPS module L1 + L2. In fact, the Mi 8 is now the most accurate GPS-module on the market among smartphones, which can actually be used for land cadastral works, provided that there is adequate software (coftu) for receiving RTK corrections from GSM base stations (Groupe Special Mobile) - channel [11-13].

The urgency of the use of modern electronic gadgets for geodetic measurements is confirmed by the studies conducted by NextNav (2018) [14]. In the course of the study, vertical position accuracy was determined with the help of different models of phones and signals from the installed network of beacons NextNav. The services provided by the NextNav's Metropolitan Beacon System (MBS) allow mobile phones and other devices to reliably determine their location in space, enclosed spaces, and urban environments, where GPS signals can not be obtained.

With regard to special applications for smartphones, for the full use of GNSS technologies, an interesting development is the soft product "GNSS Compare" [15]. This software displays general information about GNSS satellite systems, allows the user to choose the best satellite constellation for precise positioning, compare the performance of signals between different satellite systems, and so on.

\section{Conclusions}

As a result of the calculation, we obtained the following results, in particular, with an average square error of the installation of turning points up to $2 \mathrm{~cm}$, a land plot of 0.01 hectares (rectangular 4 turning points), the error of the area will be $0.8 \mathrm{~m}^{2}, 0.10$ hectares $-2.56 \mathrm{~m}^{2}, 0.25 \mathrm{ha}-4.00 \mathrm{~m}^{2}, 0.5 \mathrm{ha}$ $-5.66 \mathrm{~m}^{2}, 1$ ha $-8.00 \mathrm{~m}^{2}, 5$ ha $-17.9 \mathrm{~m}^{2}$.

Accurate surveying (determining the position of the turning points of land to $0.02 \mathrm{~m}$ ), because of its high cost, compared with others, is advisable in cases, where the market value of $1 \mathrm{~m}^{2}$ of land is reaching $207.59 \mathrm{~m}^{2} \cdot \mathrm{USD}^{-1}$ in determining the boundaries of the land plots with a total area of $0.01 \mathrm{ha}$; $64.87 \mathrm{~m}^{2} \cdot \mathrm{USD}^{-1}$ - land area of 0.10 hectares; $41.52 \mathrm{~m}^{2} \cdot \mathrm{USD}^{-1}$ - land area of 0.25 hectares; $29.34 \mathrm{~m}^{2} \cdot \mathrm{USD}^{-1}$ - land area of 0.50 hectares; $20.76 \mathrm{~m}^{2} \cdot \mathrm{USD}^{-1}$ - land area of 1.00 hectares; $9.28 \mathrm{~m}^{2} \cdot \mathrm{USD}^{-1}$ - land area of 5.00 hectares.

We are convinced that in the near future the development of technologies (software) in the field of telecommunications, satellite positioning techniques, GNSS-technologies will allow ordinary landowners to carry out land-cadastral surveys of their land plots (up to $0.5 \mathrm{~m}$ ) with the help of modern smartphones. This is confirmed by the tendency to use gadgets (special software, in particular, Pix4D, DJI Go, etc.) and unmanned aerial vehicles in the field of land cadastre, which have changed the general pursuit of aerial photography, photogrammetry as a whole. As a result, the existing technologies have allowed users to process the processing the results of photographing automatically with the help of utilities.

\section{References}

[1] Ievsiukov T., Openko I. An Inventory Database, Evaluation and Monitoring of Especially Valuable Lands at Regional Level in Ukraine. Abstracts. 3rd International Geography Symposium, Geomed 2013. Volume: 120 pp. 513-523.

[2] Zhilinsky V. L. Requirements for the accuracy of geodesic cadastral works in Ukraine. Agricultural sciences. Collection of scientific works № 21, 2013, pp. 77-82.

[3] Petrov S. L., Tserklevich A. L. Accuracy of determining the position of boundaries and areas of land for inventory of settlements. Geodesy, cartography and aerial photography. Vol. 75, 2011, pp. 62-67.

[4] Kristin M. Stock. Accuracy Requirements for Rural Land Parcel Boundaries. School of Planning, Landscape Architecture and Surveying Queensland University of Technology. Australian Surveyor, Taylor \& Francis, 1998, 10 p.

[5] Belle A. Craig and Jerry L. Wahl. Cadastral Survey Accuracy Standards. Surveying and Land Information Science, Vol. 63, No. 2, 2003, pp. 87-106.

[6] Burch T. Accuracy, precision and boundary retracement in surveying. 2017. [online] [14.03.2019] Available at: http://gpsworld.com/accuracy-precision-and-boundary-retracement-in-surveying/ 
[7] Official website. State Service of Ukraine on Geodesy, Cartography and Cadastre. Research Institute of Geodesy and Cartography. Diagram of DMM. [online] [14.03.2019] Available at: http://dgm.gki.com.ua/ua/map

[8] Resolution of the Cabinet of Ministers of Ukraine dated May 23, 2012 No. 513 "On Approval of the Procedure for Inventory of Land". [online] [14.03.2019] Available at: http://zakon.rada.gov.ua/laws/show/513-2012- \%D0 \%BF

[9] System Solutions. Rental of geodetic equipment for operation on the SystemNET network. [online] [14.03.2019] Available at:https://systemnet.com.ua/arenda-geodesy/

[10] Official website. Pension Fund of Ukraine. The average wage index for 2018 (as of 13.09.2018). [online] [14.03.2019] Available at: https://www.pfu.gov.ua/32397-pokaznyk-serednoyizarobitnoyi-platy-za-2018-rik/

[11] GPS Worldwide Laboratory: a community of knowledge-seekers spanning the globe. Laboratory A: (Multipath and GPS accuracy). [online] [14.03.2019] Available at: http://www.gpslab.org/uploads/2/3/3/5/23354588/gps_mooc_lab_a_multipath_and_accuracy.pdf

[12] Umberto R., Valerio B. and Giovanni P. Assessment of dual frequency GNSS observations from a Xiaomi Mi 8 android smartphone and positioning performance analysis. Electronics (Switzerland). Volume 8, Issue 1, 2019. [online] [14.03.2019] Available at: https://www.mdpi.com/2079-9292/8/1/91/pdf-vor

[13] Dabrowski P.S.. Accuracy of Geopotential Models Used in Smartphone Positioning in the Territory of Poland. IOP Conference Series: Earth and Environmental Science. Volume 221, Issue 1, 2019 [online] [14.03.2019] Available at: https://www.researchgate.net/publication/331451774_Accuracy_of_Geopotential_Models_Used_i n_Smartphone_Positioning_in_the_Territory_of_Poland

[14] GPS World Staff. Floor-level positioning accuracy demonstrated for indoor mobile calls. 2018. [online] [14.03.2019] Available at: http://gpsworld.com/floor-level-positioning-accuracydemonstrated-for-indoor-mobile-calls/

[15] Cozzens T. GNSS Compare app now available for download. 2018. [online] [14.03.2019] Available at: http://gpsworld.com/gnss-compare-app-now-available-for-download/ 